\title{
Analisis Tingkat Pendapatan dan Kesejahteraan Pelaku Usaha di Kawasan Wisata Pantai Pasir Putih Kabupaten Manokwari
}

\author{
Ketysia Imelda Tewernusa ${ }^{1}$, Rumas Alma Yap ${ }^{1}$, Ali Akbar Rafsanjani ${ }^{2}$ \\ ${ }^{1}$ Dosen Fakultas Ekonomi Dan Bisnis, Universitas Papua \\ ${ }^{2}$ Alumni Fakultas Ekonomi Dan Bisnis, Universitas Papua \\ Permalink/DOI: http://dx.doi.org/10.32830/jfres.v1i1.1015.g764
}

Received: April 2018; Accepted: June 2018; Published: September 2018

\begin{abstract}
Abstrak
Tujuan penelitian ini adalah untuk menganalisis tingkat pendapatan dan kesejahteraan para pelaku usaha yang memiliki usaha di kawasan wisata pantai pasir putih. Data yang diperoleh dari hasil wawancara, observasi serta telah pustaka yang dilakukan terhadap para pelaku usaha. Hasil yang diperoleh menunjukkan rata-rata pendapatan pedagang dari usaha di tempat wisata Pantai Pasir Putih masing-masing sebesar Rp 41.644.000 per tahunnya. Pendapatan per kapita pertahun Rp 17.196.181 dan termasuk dalam kategori tidak miskin dengan nilai skor 4 dan pengeluaran perkapita per tahun Rp 6.877.790, dalam jumlah ini dikategorikan tidak miskin dengan nilai skor 4. Diketahui bahwa skor rata-rata pelaku usaha di kawasan Wisata Pantai Pasir Putih adalah 30 yang termasuk dalam kategori tinggi untuk tingkat kesejahteraannya.
\end{abstract}

Kata kunci: pendapatan, pengeluaran, kesejahteraan, tempat wisata

\begin{abstract}
The purpose of this study was to analyze the level of income and welfare of business people who have businesses in white sand beach tourism areas. Data obtained from the results of interviews, observations and literature that has been carried out on business people. The results obtained show that the average income of traders from businesses in tourist attractions in Pasir Putih Beach is IDR 41,644,000 per year. Annual per capita income of Rp. 17,196,181 and included in the category of not poor with a score of 4 and per capita expenditure per year Rp. 6,877,790, in this amount categorized as not poor with a score of 4. It is known that the average score of businesses in the tourism area White Sand Beach is 30 which are categorized as high for the level of welfare.
\end{abstract}

Keywords: income, expenditures, prosperity, tourist attractions

How to Cite: Tewernusa, K.I., Yap, R.A., Rafsanjani, A.A. (2018). Analisis Tingkat Pendapatan dan Kesejahteraan Pelaku Usaha di Kawasan Wisata Pantai Pasir Putih Kabupaten Manokwari. JFRES: Journal of Fiscal and Regional Economy Studies, 1 (1), 17-25. doi: http://dx.doi.org/10.32830/jfres.v1i1.1015.g764 


\section{PENDAHULUAN}

Sebagai upaya mendorong pembangunan ekonomi maka penerimaan negara yang bersumber dari devisa negara sangat penting untuk ditingkatkan. Di berbagai negara sedang berkembang, pariwisata menduduki tempat kedua sebagai pemasok devisa negara setelah minyak, bahkan beberapa negara di kawasan Pasifik dan Amerika, industri pariwisata merupakan primadona utama pendapatan negara. Sektor pariwisata di Indonesia merupakan sektor yang strategis dan menjadi media integrasi program dan kegiatan antar sektor pembangunan, sehingga pariwisata ditetapkan menjadi leading pembangunan yang dapat menggerakkan perekonomian bangsa, dengan demikian sektor pariwisata merupakan faktor kunci dalam pendapatan, penciptaan lapangan kerja, pengembangan usaha dan infrastruktur. Berikut ini adalah tabel Produk Domestik Bruto (PDB) Sektor Pariwisata di Indonesia. Kontribusi sektor pariwisata terhadap Produk Domestik Bruto (PDB) dalam lima tahun terakhir yaitu tahun 2010-2015 selalu mengalami peningkatan. Laporan Akuntabilitas Kinerja Kementerian Pariwisata, tahun 2010 kontribusi sektor pariwisata terhadap Produk Domestik Bruto (PDB) sebesar 261,06 triliun dan tahun 2015 sebesar 461,36 triliun rupiah. Manokwari merupakan ibukota Propinsi Papua Barat yang memiliki luas wilayah 1.556,94 $\mathrm{km}^{2}$ dan berpenduduk kurang lebih 99.488 jiwa. Kabupaten Manokwari memiliki keunggulan alami karena secara geografis memiliki panorama alami dengan keindahan alam yang sangat unik, terdiri dari perbukitan, pegunungan dan laut yang kaya akan potensi sumberdaya alam dan keanekaragaman hayati sehingga potensial bagi pengembangan ekowisata. Salah satu kawasan wisata di Kabupaten Manokwari yang memiliki potensi ekonomi dan sering dikunjungi oleh wisatawan adalah Pantai Pasir Putih. Pantai Pasir Putih Manokwari terletak sekitar 5 (lima) km dari pusat Kota Manokwari. Wisata Pantai Pasir Putih merupakan salah satu tempat wisata terbaik di Kabupaten Manokwari dan hingga saat ini masih terjaga eksistensinya.
Tabel 1. Perkembangan PDB Sektor Pariwisata Indonesia (Triliun Rupiah)

\begin{tabular}{ccc}
\hline No & Tahun & Nilai PDB Pariwisata \\
\hline 1 & 2010 & 261,06 \\
2 & 2011 & 296,97 \\
3 & 2012 & 326,24 \\
4 & 2013 & 365,02 \\
5 & 2014 & 394,52 \\
6 & 2015 & 461,36 \\
\hline
\end{tabular}

Sumber: LAK Kementerian Pariwisata, 2015

Keberadaan wisata Pantai Pasir Putih merupakan sumber pendapatan bagi masyarakat Kabupaten manokwari yang menggantungkan hidupnya dengan mencari nafkah di kawasan wisata tersebut serta memberikan kontribusi besar bagi pendapatan daerah. Dampak ekonomi dari kegiatan wisata Pantai Pasir Putih berpengaruh pada peningkatan pendapatan masyarakat, perluasan lapangan pekerjaan dan perilaku masyarakat terhadap lingkungan sekitarnya. Beberapa penelitian sebelumnya melihat peran pariwisata terhadap kesejahteraan masyarakat diantaranya penelitian Indahsari dan Henny Oktavianti (2014) meneliti analisis peran pariwisata Pantai Camplong terhadap kesejahteraan masyarakat lokal dengan menggunakan metode peneltian deskriptif kuantitatif menyimpulkan bahwa pariwisata pantai camplong mempunyai peran dalam meningkatkan PAD Kabupaten Sampang walaupun kontribusinya tergolong masih kecil dan memberikan manfaat bagi masyarakat sekitar. Pantai camplong mempunyai peran dalam penyerapan tenaga kerja dan mempunyai peran terhadap peningkatan kualitas SDM melalui pelatihan dan pembinaan terhadap pelaku pariwisata seperti pedagang, tenaga kerja, masyaarakat sekitar dan sebagainya. Pantai camplong memberikan dampak positif bagi masyarakat sekitar yang terlibat alngsung dalm kegiatan wisata. Made Suyana Utama melihat pengartuh perkembangan pariwisata terhadap kinerja perekonomian dan perubahan struktur ekonomi Serta kesejahteraan masyarakat di Provinsi Bali dengan menggunakan analisis deskriptif, analisis faktor dan analisis jalur menyimpulkan bahwa perkembangan pariwisata 
berpengaruh langsung dan signifikan terhadap kinerja perekonomian di Provinsi Bali. Perkembangan pariwisata berpengaruh langsung dan tidak langsung terhadap perubahan struktur ekonomi di provinsi Bali. Perkembangan pariwisata tidak memberikan pengaruh langsung yang signifikan terhadap kesejahteraan masyarakat di Provinsi Bali. Keberadaan kawasan wisata Pantai Pasir Putih Kabupaten Manokwari semestinya berhubungan positif dengan peningkatan kesejahteraan pedagang sehingga dari sisi ekonomi bisa diketahui kontribusi wisata terhadap masyarakat yang memanfaatkan kawasan tersebut. Berdasarkan uraian yang telah dipaparkan maka penelitian ini menganalisis bagaimana tingkat pendapatan dan kesejahteraan pelaku usaha di kawasan Wisata Pantai Pasir Putih, Kabupaten Manokwari.

\section{METODE PENELITIAN}

Penelitian ini dilakukan di kawasan wisata Pantai Pasir Putih Kabupaten Manokwari. Waktu penelitian dilaksanakan selama 1 (satu) bulan. Penelitian ini menggunakan Metode deskriptif kualitatif Subjek dalam penelitian ini adalah para pelaku usaha di kawasan wisata
Pantai Pasir Putih Kabupaten Manokwari, yaitu para pedagang dan penyedia jasa wisata dan obyek Penelitian yaitu pendapatan dan kesejahteraan para pelaku usaha di kawasan wisata Pantai Pasir Putih Kabupaten Manokwari. Populasi dalam penelitian ini adalah semua para pelaku usaha yang berjualan atau berdagang di wisata Pantai pasir Putih Kabupaten Manokwari yaitu berjumlah 50 pelaku usaha. Sampel dalam penelitian ini berjumlah 25 responden Penentuan sampel menggunakan metode purposive sampling (sengaja atau dengan pertimbangan tertentu).

Pengukuran tingkat kesejahteraan rumah tangga pelaku usaha diukur berdasarkan 11(sebelas) dari 21 (dua puluh satu) Indikator Tingkat Kesejahteraan yang digunakan Badan Pusat Statisitik mengacu pada Survei Sosial Ekonomi Nasional (SUSENAS). Indikator pendapatan per kapita per tahun menggunakan indikator kemiskinan Direktorat Jendral Tata Guna Tanah melihat rasio tingkat pendapatan dengan pengeluaran. Indikator kemiskinan menurut Sajogyo sebagai indikator konsumsi rumah tangga per kapita per tahun. Seperti terlihat pada bagan berikut ini.

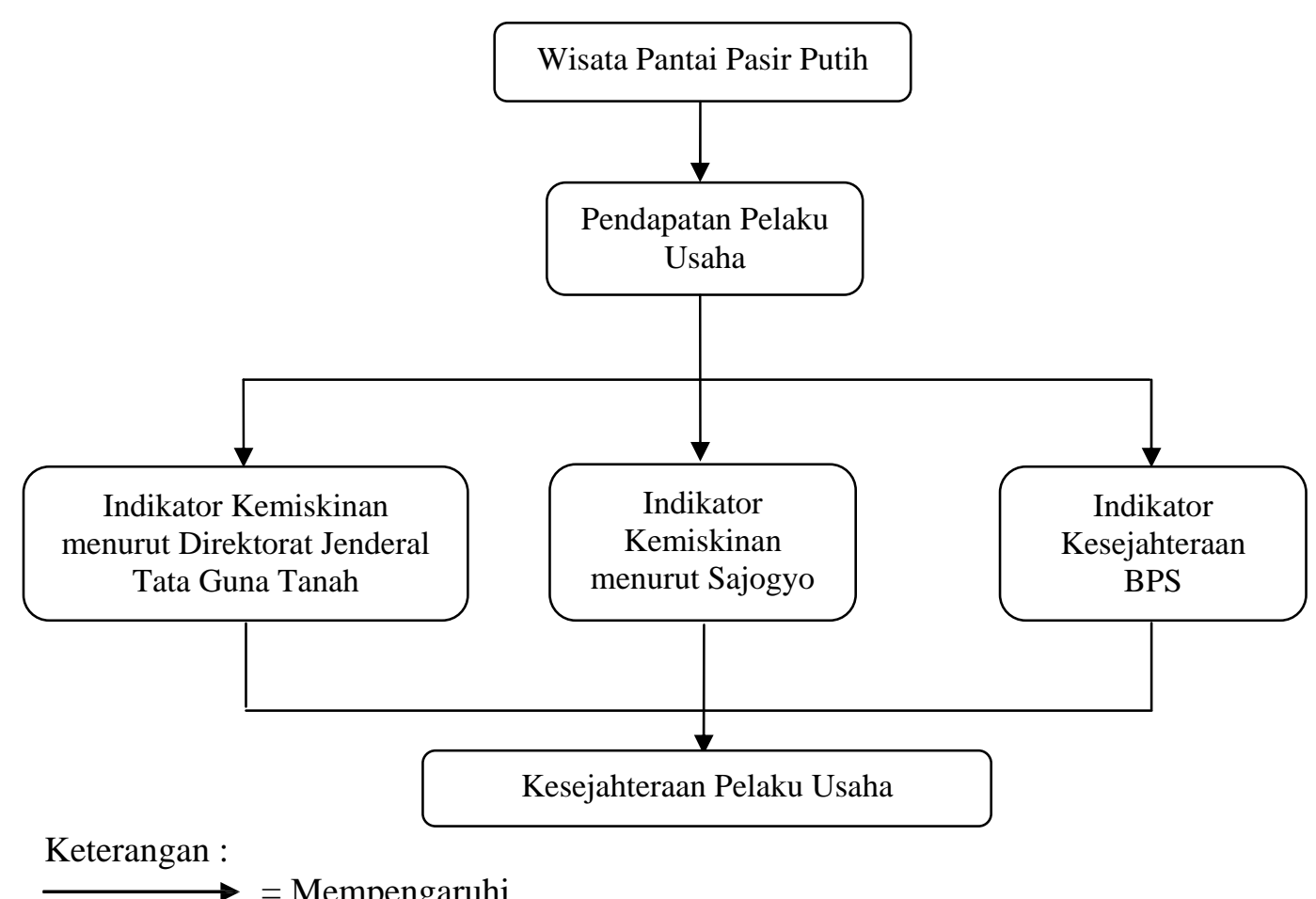

Gambar 1. Kerangka Pemikiran 
Klasifikasi tingkat kesejahteraan dicari dengan menggunakan metode skoring baru dari Badan Pusat Statistik, dimana skor range akan dihitung dengan cara menggunakan skor tertinggi dengan jumlah skor terendah dari kesebelas indikator kesejahteraan yang telah ditentukan sebelumnya dan hasil pengurangan tersebut dibagi dengan jumlah klasifikasi tingkat kesejahteraan yang akan diturunkan, yaitu tiga klasifikasi. Jumlah skor tertinggi dari sebelas indikator kesejahteraan adalah 35 dan jumlah skor terendah adalah 11, maka range-nya adalah (3511) $/ 3=8$. Sehingga jika diturunkan berdasarkan tingkat klasifikasi kesejahteraan adalah sebagai berikut:

a. Tingkat kesejahteraannya tinggi jika mencapai sko $r=27-35$

b. Tingkat kesejahteraannya sedang jika mencapai sko $r=19-27$

c. Tingkat kesejahteraannya rendah jika mencapai skor $=11-19$

\section{HASIL DAN PEMBAHASAN}

Pelaku usaha yang menjadi responden dalam penelitian ini adalah mereka yang memiliki usaha di kawasan Wisata Pantai Pasir Putih dan telah berumah tangga. Penentuan jumlah responden sebanyak 25 responden. Adapun responden pelaku usaha terdiri dari 8 pelaku usaha gado-gado dan rujak, jasa sewa benen dan karpet berjumlah 6 pelaku usaha, 1 jasa sewa toilet, 3 pedagang bakso, 2 pedagang sate, 2 pedagang es buah, 1 pedagang kelapa muda, serta 2 pedagang minuman dan pinang.

Karateristik responden pelaku usaha berdasarkan jenis kelamin terdiri dari 14 responden perempuan dan 11 responden laki-laki. Usia responden berkisar antara 27 hingga 67 tahun. Untuk usia 27 hingga 57 tahun sebanyak 23 orang, sedangkan kelompok usia 58 hingga 67 berjumlah 2 orang. Lama usaha yang dijalankan oleh pelaku usaha atau responden mulai dari 1 tahun hingga 23 tahun. Responden yang telah berjualan kurang dari 10 tahun sebanyak 21 orang, jumlah responden yang berjualan lebih dari 11 tahun sebanyak 4 orang. Dilihat dari tingkat pendidikan responden berlatar belakang pendidikan SMA dan sederajat sebanyak 17 orang, responden yang menyelesaikan pendidikan SMP berjumlah 5 orang dan responden yang menyelesaikan pendidikan SD berjumlah 3 orang. Sebagian besar responden memiliki anggota keluarga sebanyak 3-6 orang, sedangkan 4 responden memiliki anggota keluarga sebanyak 7-9 orang. Pendapatan rumah tangga adalah jumlah pendapatan yang diperoleh dari hasil kerja anggota rumah tangga (suami, istri, dan anak). Pendapatan yang diperoleh pelaku usaha berasal dari usaha yang dimiliki di pantai pasir putih atau atau kegiatan usaha di luar pasir putih. Rata-rata pendapatan pedagang dari usaha wisata Pantai Pasir Putih sebesar Rp 41.644.000 per tahunnya. Pendapatan pelaku usaha berkisar antara Rp 14.400.000 sampai Rp 72.000.000 per tahun, dimana pendapatan terbesar berasal dari jenis usaha gado-gado dan rujak sedangkan pendapatan terkecil berasal dari jenis usaha bakso. Pengeluaran atau konsumsi per kapita per tahun responden pedagang dapat dibedakan menjadi dua, yaitu konsumsi pangan dan non pangan. Rata-rata pengeluaran per kapita per tahun responden rumah tangga pelaku usaha adalah sebesar Rp 6.877.790. Adapun pengeluaran per kapita per tahun responden rumah tangga pedagang berkisar dari Rp 2.333.333 sampai Rp 12.000.000. Pengeluaran per kapita per tahun terkecil berasal dari responden penjual kelapa muda dan terbesar berasal dari keluarga responden penjual gado-gado, rujak, jasa sewa bantal berenang dan karpet.

Tabel 2. Kriteria Kemiskinan Menurut Direktorat Jenderal Tata Guna Tanah

\begin{tabular}{ccc}
\hline Presentase & Pendapatan & Kriteria \\
\hline$>200 \%$ & $>$ Rp 5.625.000 & Tidak Miskin \\
$125-200 \%$ & Rp 3.516.250 - Rp 5.625.000 & Hampir Miskin \\
$75-125 \%$ & Rp 2.109.750 - Rp 3.516.250 & Miskin \\
$75 \%$ & Rp 2.109.750 & Paling Miskin \\
\hline
\end{tabular}

Sumber: Data Primer Diolah, 2015 
Kriteria kemiskinan menurut Direktorat Jenderal Tata Guna Tanah menggunakan pendekatan pendapatan per kapita per tahun responden rumah tangga pelaku usaha yang dibandingkan dengan konsumsi kebutuhan sembilan bahan pokok dalam setahun sesuai harga yang berlaku di daerah penelitian. Peniliaian tingkat kesejahteraan rumah tangga responden menggunakan kriteria Badan Pusat Statisik (BPS) dalam SUSENAS 1991 yang dimodifikasi, yaitu dengan memasukkan kriteria kemiskinan Sajogyo dan kriteria kemiskinan Direktorat Jenderal Tata Guna Tanah. Indikator kesejahteraan yang diukur menurut BPS pada SUSENAS 1991 yang dimodifikasi antara lain yaitu:

1. Pendapatan rumah tangga

2. Konsumsi rumah tangga

3. Keadaan tempat tinggal

4. Fasilitas tempat tinggal

5. Kesehatan anggota rumah tangga

6. Kemudahan mendapatkan pelayanan kesehatan dari tenaga medis/paramedis (termasuk didalamnya kemudahan mengikuti Keluarga Berencana (KB) dan memperoleh obat-obatan

7. Kemudahan memasukkan anak ke jenjang pendidikan

8. Kemudahan mendapatkan fasilitas transportasi (pengangkutan)
9. Kehidupan beragama

10. Rasa aman dari tindakan kejahatan

11. Kemudahan dalam melakukan kegiatan olahraga

Berdasarkan tabel di bawah responden atau pelaku usaha yang termasuk kategori tidak miskin sebanyak 24 keluarga dan kategori hampir miskin sebanyak 1 keluarga. Pengeluaran rumah tangga menurut kriteria kemiskinan Sajogyo adalah pengeluaran per kapita per tahun. Pengeluaran per kapita per tahun diperoleh dengan cara membagi total pengeluaran per tahun dengan jumlah anggota keluarga. Untuk membandingkan kriteria kemiskinan Sajogyo dengan pengeluaran per kapita per tahun dari rumah tangga harus ditentukan dari harga ratarata beras dipasaran pada saat penelitian yaitu sebesar Rp 10.000 per kilogram. Berikut adalah tabel empat kriteria konsep kemiskinan Sajogyo yaitu:

Responden pelaku usaha yang termasuk kategori tidak miskin berjumlah 22 keluarga, kategori hampir miskin, miskin dan miskin sekali masing-masing hanya 1 keluarga.

Keadaan tempat tinggal responden yang bertempat tinggal permanen sebanyak 15 keluarga dan semi permanen sebanyak 10 keluarga. Indikator keadaan tempat tinggal terdiri dari beberapa unsur di antaranya adalah: jenis atap, bilik, status

Tabel 3. Tingkat Kemiskinan Responden Pedagang Menurut Direktorat Jenderal Tata Guna Tanah

\begin{tabular}{clc}
\hline No & \multicolumn{1}{c}{ Kriteria } & $\begin{array}{c}\text { Jumlah } \\
\text { Responden } \\
\text { (Keluarga) }\end{array}$ \\
\hline 1 & Tidak Miskin (pendapatan perkapita per tahun > Rp 5.625.000 & 24 \\
2 & Hampir Miskin (pendapatan perkapita per tahun >Rp 3.516.250 s.d Rp 5.625.000) & 1 \\
3 & Miskin (pendapatan per kapita per tahun antara Rp 2.109.750 s.d Rp 3.516.250) & \\
4 & Paling Miskin (pendapatan per kapita per tahun < Rp 2.109.750) & $\mathbf{2 5}$ \\
\hline & Jumlah & \\
\hline
\end{tabular}

Sumber: Data Primer diolah, 2017

Tabel 4. Kriteria Kemiskinan Menurut Sajogyo

\begin{tabular}{ccc}
\hline Presentase & Pendapatan & Kriteria \\
\hline$>480 \%$ & $>$ Rp 4.800.000 & Tidak Miskin \\
$360-480 \%$ & Rp 3.600.000 - Rp 4.800.000 & Hampir Miskin \\
$240-360 \%$ & Rp 2.400.00 - Rp 3.600.000 & Miskin \\
$<240 \%$ & $<$ Rp 2.400.000 & Paling Miskin \\
\hline
\end{tabular}

Sumber: Data Primer diolah, 2017

Journal of Fiscal and Regional Economy Studies 
kepemilikan, jenis lantai, dan luas bangunan. Keadaan tempat tinggal dibedakan menjadi tiga kategori yaitu: permanen dengan skor 15-21, semi permanen dengan skor 10-14, non permanen skor 5-9 keadaan tempat tinggal responden yang bertempat tinggal permanen sebanyak 15 keluarga dan semi permanen sebanyak 10 keluarga. Indikator tempat tinggal rumah tangga pelaku usaha, hasil yang diperoleh sebanyak 25 reponden yang menggunakan seng. Untuk jenis bilik tembok sebanyak 15 responden, setengah tembok 3 responden, dan kayu 7 responden. Untuk jenis status kepemilikan sebanyak 20 responden yang memiliki rumah sendiri, 4 responden sewa dan 1 responden menumpang. Sebanyak 13 respoden yang menggunakan jenis lantai tehel dan 12 responden menggunakan plester semen. sebanyak 19 responden memiliki jenis luas bangunan kurang dari $50 \mathrm{~m}^{2}$ dan 2 responden memiliki luas bangunan $50-100 \mathrm{~m}^{2}$.

Indikator fasilitas tempat tinggal terdiri dari beberapa unsur di antarannya adalah: luas pekarangan rumah, hiburan alat pendingin, sumber penerangan, bahan bakar yang digunakan, sumber air, dan fasitas MCK yang dimiliki. Keadaan fasilitas tinggal dibedakan menjadi tiga kategori yaitu: lengkap dengan skor 21-27, cukup dengan skor 14-20, kurang skor 7-13. Sebanyak 10 responden memiliki fasilitas tempat tinggal yang lengkap dan sebanyak 15 responden yang memiliki fasilitas tempat tinggal yang cukup. Indikator kesehatan ini melihat seberapa banyak anggota rumah tangga yang sakit dalam satu bulan. Kesehatan anggota rumah tangga pelaku usaha dibagi 3 kategori yaitu, kategori bagus kurang dari 25\% (skor 3), cukup 25-50\% (skor 2), dan kategori kurang lebih dari 50\% (skor 1). Berdasarkan data yang diperoleh dapat menunjukkan kesehatan keluarga responden pelaku usaha termasuk dalam kategori bagus sebanyak 25 responden. Indikator kemudahan mendapatkan pelayanan kesehatan bahwa menunjukan sebanyak 14 responden yang mengatakan mudah mendapatkan pelayanan kesehatan, 9 responden mengatakan cukup dan 2 responden yang mengatakan sulit mendapatkan pelayanan kesehatan.

Indikator kemudahan memasukkan anak ke jenjang pendidikan terdiri dari beberapa unsur, yaitu: biaya sekolah, jarak ke sekolah, prosedur penerimaan. Pada indikator ini digolongkan menjadi tiga kategori yaitu: mudah (skor 8-10), cukup (skor 6-7), dan sulit (skor 4-5). Bahwa sebagian besar untuk biaya sekolah sebanyak 17 responden mengatakan terjangkau, untuk jarak ke sekolah sebanyak 15 responden mengatakan cukup dan untuk prosedur penerimaan sebagian besar responden mengatakan mudah memasukkan anak ke jenjang pendidikan.

Indikator kemudahan mendapatkan fasilitas transportasi mencakup ongkos dan biaya, fasilitas kendaraan, dan kepemilikan kendaraan. Pada indikator ini terbagi menjadi 3 kategori yaitu mudah (skor 7-9), cukup (skor 5-6), dan sulit (skor 3-4). Bahwa sebanyak 14 responden yang mengatakan mudah mendapatkan fasilitas transportasi, sebanyak 9 responden mengatakan cukup dan sebanyak 2 responden mengatakan sulit.sebanyak 16 responden mengatakan ongkos dan biaya terjangkau, sebanyak 19 responden mengatakan cukup tersedia, kemudian untuk kepemilikan kendaraan 21 responden mengatakan memiliki kendaraan sendiri. Indikator kehidupan beragama dilihat dari toleransi antar umat beragama. Pada indikator ini terbagi atas 3 kategori yaitu toleransi tinggi (skor 3), toleransi cukup (skor 2), toleransi kurang (skor 1). Berdasarkan data tabel 6 data yang diperoleh

Tabel 5. Tingkat Kemiskinan Responden Pedagang

\begin{tabular}{llc}
\hline No & \multicolumn{1}{c}{ Kriteria } & $\begin{array}{c}\text { Jumlah Responden } \\
\text { (Keluarga) }\end{array}$ \\
\hline 1 & Tidak Miskin (pengeluaran perkapita per tahun > Rp 4.800.000) & 22 \\
2 & Hampir Miskin (pengeluaran perkapita per tahun lebih dari Rp3.600.000 s.d Rp 4.800.000) & 1 \\
3 & Miskin (pengeluaran per kapita per tahun antara Rp 2.000.00 s.d Rp 3.600.000) & 1 \\
4 & Paling Miskin (pengeluaran perkapita per tahun < Rp 2.400.000) & 1 \\
\hline & Jumlah & $\mathbf{2 5}$ \\
\hline
\end{tabular}

Sumber: Data Primer diolah, 2017

Journal of Fiscal and Regional Economy Studies 
diketahui bahwa sebanyak 19 rsponden mengatakan memiliki kehidupan dengan toleransi tinggi, dan sebanyak 6 mengatakan toleransi cukup. Indikator rasa aman didasarkan pada sering atau tidaknya terjadi tindak kejahatan di lingkungan tempat tinggal. Pada indikator ini terbagi atas 3 kategori yaitu rasa aman (tidak pernah mengalami gangguan kejahatan), cukup aman (pernah mengalami gangguan kejahatan), dan rasa kurang aman (sering pernah mengalami gangguan kejahatan). Bahwa sebanyak 15 responden yang mengatakan aman dari kejahatan dan sebanyak 10 responden yang mengatakan cukup aman dari gangguan kejahatan. Indikator Kemudahan melakukan olahraga ditunjang dengan keberadaan fasilitas olahraga baik itu ketersediaan lahan berupa lapangan dan peralatan olahraga. Berdasarkan data dari sebanyak 20 responden yang mengatakan sulit mendapatakan kegiatan berolahraga karena sebagian besar dari jumlah responden selalu melakukan kegiatan usaha sehingga sulit untuk berolahraga dan sebanyak 5 responden mengatakan cukup mudah memperoleh kegiatan olahraga.

Tabel 6. Skor Tingkat Kesejahteraan

\begin{tabular}{ccc}
\hline Tingkat Kesejahteraan & Skor & $\begin{array}{c}\text { Jumlah } \\
\text { Responden } \\
\text { (orang) }\end{array}$ \\
\hline Tingkat Kesejahteraan Tinggi & $27-35$ & 24 \\
Tingkat Kesejahteraan Sedang & $19-25$ & 1 \\
Tingkat Kesejahteraan Rendah & $11-18$ & 0 \\
\hline Total & & $\mathbf{2 5}$ \\
\hline
\end{tabular}

Sumber: Data Primer diolah, 2017

Pengukuran tingkat kesejahteraan berdasarkan 11 indikator kesejahteraan menurut Badan Pusat Statistik pada SUSENAS 1991 yang dimodifikasi membagi tiga kategori tingkat kesejahteraan, yaitu tingka kesejahteraan tinggi (skor 27-35), tingkat kesejahteraan sedang (skor 1926), dan tingkat kesejahteraan rendah (skor 1118). Berdasarkan perhitungan tabel 6 diketahui bahwa sebagian besar dari 25 jumlah responden yang memilik tingkat kesejahteraan yang tinggi sebanyak 24 responden dan 1 responden yang memiliki tingkat kesejahteraan sedang. Hal ini di sebabkan karena pada responden tersebut memiliki jumlah anggota keluarga yang cukup banyak yaitu 9 anggota sedangkan pendapatan dari usaha wisata dan di luar usaha wisata kurang mencukupi serta tingkat kesejahteraan responden tersebut dapat dikatakan sedang.

Hasil data yang diperoleh dari masing-masing responden tentang hasil pendapatan selama satu tahun rata-rata pendapatan pelaku usaha dari usaha wisata Pantai Pasir Putih sebesar Rp 41.644.000 per tahunnya. Pendapatan pelaku usaha berkisar antara Rp 14.400.000 sampai Rp 72.000.000 per tahun. Pendapatan terkecil berasal dari jenis usaha bakso sedangkan pendapatan terbesar berasal dari jenis usaha gado-gado dan rujak. Pendapatan terbesar berasal dari jenis usaha gado-gado dan rujak karena pelaku usaha gado-gado dan rujak memiliki banyak pelanggan serta termasuk makanan favorit di kawasan wisata Pantai Pasir Putih sehingga memiliki keuntungan yang paling besar dibandingkan unit usaha lainnya dari setiap jenis usaha yang terjual. Sedangkan pendapatan terkecil berasal dari jenis usaha bakso, hal ini disebabkan karena pedagang hanya berjualan pada saat hari minggu dan terdapat banyak sekali penjual bakso sehingga memiliki keuntungan yang paling kecil tiap minggunya dibandingkan jenis usaha lainnya. Sebagian besar penjual bakso biasanya hanya berjualan pada hari sabtu dan minggu serta hari libur nasional, mereka tidak berjualan di hari biasa karena sangat sepi pembeli. Menurut mereka alasan untuk tidak berjualan di hari biasa karena keuntungan yang diperoleh pada hari biasa tidak sebanding dengan keuntungan di luar kawasan pantai Psair Putih, biaya dan curahan waktu kerja yang dikeluarkan mereka.

Dari pengukuran dengan menggunakan Indikator Kesejahteraan menurut BPS dalam Susenas 1991 yang telah dimodifikasi, diperoleh hasil bahwa skor rata-rata pelaku usaha di kawasan Wisata Pantai Pasir Putih adalah 30 responden yang termasuk dalam kategori Tinggi tingkat Kesejahteraannya. Untuk mengetahui indikator kesejahteraan pendapatan pelaku usaha menggunakan kriteria kemiskinan menurut Direktorat Jenderal Tata Guna Tanah. Berdasarkan hasil yang telah dipaparkan sebelumnya bahwa ada sebanyak 24 responden atau keluarga yang termasuk dalam kategori tidak miskin, hal ini disebabkan karena pendapatan perkapita pertahun yang diperoleh 
lebih besar dan memiliki jumlah anggota keluarga tergolong rendah sedangkan responden yang termasuk kategori hampir miskin yaitu penjual kelapa muda, hal ini disebabkan karena pendapatan perkapita per tahun tergolong rendah dan memiliki jumlah anggota keluarga sebanyak 9 orang. Jadi dapat disimpulkan bahwa skor pendapatan perkapita per tahun adalah 4 (tidak miskin). Kemudian untuk mengetahui tingkat kesejahteraan konsumsi rumah tangga menggunakan kriteria kemiskinan Sayogyo. Hasil yang telah diperoleh sebelumnya bahwa terdapat 22 responden keluarga termasuk dalam kategori tidak miskin. Sedangkan untuk responden yang termasuk dalam kategori hampir miskin, miskin dan miskin sekali masing-masing sebanyak 1 responden keluarga hal disebabkan karena memiliki jumlah anggota keluarga yang cukup banyak. Jadi dapat disimpulkan bahwa skor pengeluaran perkapita per tahun adalah 4 (tidak miskin).

Berdasarkan analisis dan perhitungan yang telah dilakukan sebelumnya, bahwa kondisi tempat tinggal rumah tangga responden dikategorikan permanen dengan skor 15-21 (nilai 3). Hal ini disebabkan karena karateristik responden pada umumnya memperhatikan kondisi lingkungan dan tempat tinggal mereka, serta adanya berbagai anggapan di kalangan responden rumah tangga bahwa tempat tinggal yang mereka tempati perlu diperlakukan secara maksimal mengingat status kepemilikan tempat tinggal. Adapun fasilitas tempat tinggal responden berada pada kategori cukup dengan (skor 14-20) dengan nilai 2. Hal ini sebagai akibat dari adanya beberapa fasilitas tempat tinggal yang sulit dipenuhi seperti luas pekarangan yang dimiliki cukup sempit kemudian ada beberapa anggapan bahwa sebagian besar masyarakat ratarata menggunakan bahan bakar minyak tahah untuk memasak serta ada beberapa responden yang tidak mendapatkan pelayanan air PDAM dan beberapa dari mereka yang mneggunakan sumur bor.

Kondisi kesehatan anggota rumah tangga responden bisa dikatakan cukup terjamin, mengingat besarnya kepedulian dan perhatian pemerintah pada bidang penyediaan pelayanan kesehatan. Hal ini dibuktikan dengan hasil yang didapat sebelumnya, bahwa kesehatan anggota rumah tangga responden termasuk dalam kategori bagus $(<25 \%)$ skor 3. Berdasarkan kondisi kesehatan anggota rumah tangga responden, maka sudah dapat dipastikan bahwa tingkat kemudahan mendapatkan pelayanan kesehatan termasuk dalam kategori mudah (skor 18-24\%) dengan nilai 3.

Indikator kemudahan memasukkan anak ke jenjang pendidikan responden rumah tangga dapat dikategorikan mudah (skor 8-10) dengan nilai 3, hal ini disebabkan penyediaan sarana pendidikan yang juga merupakan tugas pemerintah dalam hal ini merupakan satu paket dengan penyediaan pelayanan kesehatan masyarakat untuk menciptakan dan meningkatakan kualitas sumberdaya manusia. Aktivitas ekonomi daerah wisata Pantai Pasir Putih tergolong tinggi, dengan kondisi tersebut tentu memerlukan ketersediaan sarana pendukung. Kemudahan alat transportasi dapat dikategorikan cukup (skor 5-6) dengan nilai 2. Berdasarkan hasil yang diperoleh bahwa sebagian besar kepemilikan kendaraan milik pribadi. Adapun ongkos dan biaya tranportasi yang pada umumnya menurut responden cukup terjangkau.

Kehidupan beragama dan tingkat keamanan di lingkungan tempat tinggal maupun wisata Pantai Pasir Putih tempat berjualan berada pada kategori toleransi tinggi dengan nilai 3 dan tingkat keamanan yang berada pada kategori cukup aman dengan nilai 2. Hal ini dikarenakan cukup sering terjadinya gangguan atau konflik di kawasan tempat berjualan maupun tempat tinggal responden namun masih dalam batas kewajaran. Pada umumnya anggapan responden terhadap tingginya toleransi kehidupan beragama sangat dijunjung tinggi. Hanya saja, toleransi tinggi umat beragama tidak dibarengi dengan penyediaan tempat ibadah di sekitar kawasan wisata pantai pasir putih, yang sedikit banyaknya mempengaruhi aktivitas ibadah. Berdasarkan penjelasan yang telah dipaparkan sebelumnya bahwa sebagian besar responden sulit melakukan kegiatan berolahraga karena responden selalu melakukan kegiatan usaha sehingga sulit untuk berolahraga. Oleh sebab itu, sudah dapat dipastikan bahwa tingkat kemudahan berolahraga dikategorikan sulit dengan 
nilai 1 , namun banyak anggapan bahwa keadaan ini tidak dijadikan sebagai suatu masalah atau kerugian bagi para responden.

\section{KESIMPULAN}

1. Rata-rata pendapatan pedagang dari usaha wisata Pantai Pasir Putih masing-masing sebesar Rp 41.644.000 per tahunnya. Pendapatan per kapita pertahun Rp 17.196.181 dan termasuk dalam kategori tidak miskin dengan nilai skor 4 dan pengeluaran perkapita per tahun Rp 6.877.790, dalam jumlah ini dikategorikan tidak miskin dengan nilai skor 4 .

2. Tingkat kesejahteraan pedagang menurut 11 Indikator yang digunakan BPS dalam SUSENAS 1991 yang telah dimodifikasi diketahui bahwa skor rata-rata pelaku usaha di kawasan Wisata Pantai Pasir Putih adalah 30 yang termasuk dalam kategori Tinggi tingkat Kesejahteraannya.

\section{DAFTAR PUSTAKA}

Anonim. 2017. "Dinas Kebudayaan, Pariwisata, Pemuda dan olahraga”. Kabupaten Manokwari Propinsi Papua Barat.

Anonim. 2015. "Laporan Akuntabilitas Kinerja Kementerian Pariwisata Republik Indonesia".

Badan Pusat Statistik. 2009. Indikator Kesejahteraan Rakyat 2009. Badan Pusat Statistik. Jakarta.

Badan Pusat Statistik. 2011. Perhitungan dan Analisis Kemiskinan Makro Indonesia Tahun 2011. Badan Pusat Statistik. Jakarta

Biro Kepegawaian dan Hukum. 2005. Naskah Akademik Rancangan Undang- Undang Sistem Kesejahteraan Sosial Nasional. Departeman Sosial RI. Jakarta

Indahsari, Kurniyati, dan Oktaviavianti, Henny. "Analisis Peran Pariwisata Pantai Camplong Terhadap Kesejahteraan Masyarakat Lokal”. Universitas Trunojoyo Madura, vol.9 No.2. (2 oktober 2014). 